\title{
Pengaruh Mobilisasi Dini Pasien Pasca Operasi Abdomen Terhadap Penyembuhan Luka Dan Fungsi Pernafasan
}

\author{
Reni Prima Gusty ${ }^{\mathrm{a}}$ \\ Program Studi Ilmu Keperawatan FK UNAND \\ Email: reni.rafie@gmail.com
}

\begin{abstract}
Injury and pain resulted from surgery makes the patient too lazy to move so delays wound healing and leads respiratory complications mobilization is a prominent factor in accelerating wound healing and optimal postoperative respiratory function. Type of research is Quasi-experimental approach to posttest control group design. Research objectives were to determine the effect of early mobilization after abdominal surgery on wound healing and respiratory function. sample were 40 patients who undergone abdominal surgery room in IRNA RSUP DR. M. Djamil Padang. Analysis using Mann Whitney test. The results showed there were significant differences in wound healing and respiratory function of patients with postoperative abdominal between groups that do not perform according to the procedure of early mobilization (control) with early mobilization group that according to the procedure (treatment) for major surgery with $p=$ 0.000. there were no significant differences in respiratory function of patients post abdominal surgery between the control group with treatment for minor surgery with $p=$ 0.067 and there were significant differences in wound healing of the patient post abdominal surgery between the control group with treatment for minor surgery with $p$ $=0.000$. Hospital is expected to provide facilities to the smooth extension of early mobilization after surgery and nurses implementasi early mobilitation in nursig care plan for recovery wound and increase respiratory function.
\end{abstract}

Keywords: early mobilization, wound healing, respiratory function

\begin{abstract}
Abstrak : Luka dan nyeri akibat pembedahan luka membuat pasien malas bergerak sehingga banyak luka operasi yang mengalami keterlambatan penyembuhan serta terjadi komplikasi gangguan pernafasan. Mobilisasi dini merupakan faktor yang menonjol dalam mempercepat penyembuhan luka pasca bedah serta optimalnya fungsi pernafasan. Jenis penelitian ini adalah Quasi-eksperimental dengan pendekatan posttest control group design. Tujuan penelitian untuk mengetahui pengaruh mobilisasi dini pasca pembedahan abdomen terhadap penyembuhan luka operasi abdomen dan fungsi pernafasan. Sampelnya 40 pasien pasca operasi abdomen yang dirawat diruang IRNA Bedah RSUP DR. M. Djamil Padang. Analisa menggunakan Uji Mann Whitney. Hasil penelitian menunjukkan terdapat perbedaan penyembuhan luka dan fungsi pernafasan pasien post operasi abdomen antara kelompok yang tidak melakukan mobilisasi dini sesuai prosedur (kontrol) dengan kelompok yang melakukan mobilisasi dini sesuai prosedur perlakuan untuk bedah mayor dengan $\mathrm{p}=0.000$. tidak terdapat perbedaan pada fungsi pernafasan pasien post operasi abdomen antara kelompok kontrol dengan perlakuan untuk bedah minor dengan $p=0,067$ dan terdapat perbedaan bermakna penyembuhan luka pasien post operasi abdomen antara kelompok kontrol dengan perlakuan untuk bedah minor dengan $p=0,000$. Diharapkan RS menyediakan sarana dan prasana untuk kelancaran penyuluhan mobilisasi dini pasca pembedahan dan perawat melakukan intervensi mobilisasi dini dalam setiap pemberian asuhan keperawatan pada pasien post operasi abdomen guna mempercepat penyembuhan luka $\&$ peningkatan fungsi pernafasan.
\end{abstract}

Kata kunci : mobilisasi dini, penyembuhan luka, fungsi pernafasan 
Tindakan pembedahan merupakan salah satu pilihan untuk mengatasi masalah penyakit atau kesehatan pada praktik kedokteran modern. Luka akibat pembedahan pada umumnya berukuran besar dan dalam, sehingga membutuhkan waktu penyembuhan yang lama (Priharjo.,1992). Ada beberapa masalah yang sering muncul pada paska pembedahan diantaranya luka akan mengalami stress selama masa penyembuhan akibat dari nutrisi yang tidak adekuat,gangguan sirkulasi dan perubahan metabolisme yang dapat memperlambat penyembuhan luka (Potter\& Perry,2006). Efek lain yang dapat ditimbulkan akibat paska pembedahan adalah gangguan pernafasan akibat anestesi yang diberikan dan obat nyeri paska operasi. Keduanya dapat menekan pusat pernafasan sehingga akan menurunkan frekuensi pernafasan dan pengembangan paru, tindakan nafas dalam dan batuk efektif akan membantu mengurangi depresi pernafasan (Potter \& Perry,2006).

Mobilisasi merupakan faktor yang menonjol dalam mempercepat penyembuhan atau pemulihan luka pasca bedah serta optimalnya fungsi pernafasan. Banyak keuntungan yang dapat diraih dari latihan naik turun tempat tidur dan berjalan pada periode dini pasca bedah, diantaranya peningkatan kecepatan kedalaman pernapasan, peningkatan sirkulasi, peningkatan berkemih dan metabolisme (Taylor, 1997). Mobilisasi akan mencegah kekakuan otot dan sendi hingga juga mengurangi nyeri, menjamin kelancaran peredaran darah, memperbaiki pengaturan metabolisme tubuh, mengembalikan kerja fisiologis organ-organ vital yang pada akhirnya justru akan mempercepat penyembuhan luka. Menggerakkan badan atau melatih kembali otot-otot dan sendi pasca operasi di sisi lain akan memperbugar pikiran dan mengurangi dampak negatif dari beban psikologis yang tentu saja berpengaruh baik juga terhadap pemulihan fisik.

Mobilisasi sudah dapat dilakukan sejak 6 jam setelah pembedahan, tentu setelah pasien sadar atau anggota gerak tubuh dapat digerakkan kembali setelah dilakukan pembiusan regional. pasien pasca operasi diharapkan dapat melakukan mobilisasi sesegera mungkin, seperti melakukan gerakan kaki, bergeser di tempat tidur, melakukan nafas dalam dan batuk efektif dengan membebat luka atau dengan jalinan kedua tangan di atas luka operasi, serta teknik bangkit dari tempat tidur (Brunner \& Suddarth, 1996). Long, (1998) juga menyatakan bahwa mobilisasi dini mempunyai manfaat untuk peningkatan sirkulasi darah yang dapat menyebabkan pengurangan rasa nyeri, mencegah tromboflebitis, memberi nutrisi untuk penyembuhan pada daerah luka, dan meningkatkan kelancaran fungsi ginjal.

Mobilisasi secara tahap demi tahap sangat berguna untuk membantu jalannya penyembuhan pasien. Secara psikologis mobilisasi akan memberikan kepercayaan pada pasien bahwa dia mulai merasa sembuh (Rustam Muchtar, 1992)

Pembedahan mengakibatkan timbulnya luka dan nyeri pada bagian tubuh pasien. Rasa nyeri setelah pembedahan biasanya berlangsung 24 sampai 48 jam, namun dapat berlangsung lebih lama tergantung pada luas luka, penahan nyeri yang dimiliki pasien dan respon terhadap nyeri. Nyeri dapat memperpanjang masa penyembuhan, karena mengganggu kembalian aktifitas/mobilisasi pasien dan hal ini yang menjadi salah satu alasan pasien untuk tidak mau bergerak atau melakukan mobilisasi segera (Long, 1998).

Kebanyakan dari pasien masih mempunyai kekhawatiran kalau tubuh digerakkan pada posisi tertentu pasca operasi akan mempengaruhi luka operasi yang masih belum sembuh yang baru saja selesai dikerjakan. Padahal tidak sepenuhnya masalah ini perlu dikhawatirkan, bahkan justru hampir semua jenis operasi membutuhkan mobilisasi atau pergerakan badan sedini mungkin. Asalkan rasa nyeri dapat ditahan dan keseimbangan 
tubuh tidak lagi menjadi gangguan, dengan bergerak, masa pemulihan untuk mencapai level kondisi seperti pra pembedahan dapat dipersingkat (Brunner \& Suddarth, 1996).

Pembedahan abdomen adalah pembedahan yang dilakukan pada bagian abdomen. Kecepatan pemulihan pada luka abdomen lebih cepat bila mobilisasi dini dilakukan, kejadian eviserasi pascaoperatif pada serangkaian kasus akan jarang terjadi bila pasien segera melakukan mobilisasi. Untuk operasi di perut, jika tidak ada perangkat tambahan yang menyertai pasca operasi, tidak ada alasan untuk berlamalama berbaring di tempat tidur (Setiawan Eka, 2010).

Dari data yang diperoleh di ruang IRNA (B) bedah RSUP DR. M. Djamil bulan Agustus-Oktober 2009 dari 132 orang pasien pasca operasi yang mengalami penyembuhan luka lambat sebanyak 78 orang $(59,1 \%)$ dengan lama perawatan ratarata 8-10 hari dan penyembuhan luka normal sebanyak 54 orang $(40,9 \%)$ dengan lama rawat kurang dari 8 hari. Hal ini sejalan dengan penelitian yang pernah dilakukan Syahlinda (2008), bahwa pasien yang menjalani operasi laparatomi di IRNA B (bedah) RSUP M. Jamil Padang pada bulan Juli-Oktober 2007 mengalami penyembuhan luka insisi pasca operasi laparatomi dengan tidak terjadi komplikasi $37,9 \%$ dalam 5- 10 hari perawatan dan mengalami penyembuhan luka dengan komplikasi $62,1 \%$ dalam 11- 56 hari perawatan.

Hasil observasi peneliti dari tanggal 2-22 februari 2010 dari 12 orang yang mengalami luka abdomen (laparatomi), 10 orang tidak melakukan mobilisasi, posisinya hanya telentang di tempat tidur. Sedangkan 2 orang lagi melakukan mobilisasi namun tidak beraturan. Dari hasil wawancara pasien mengatakan merasa takut bila jahitan robek, nyeri bila melakukan gerakan,dan takut akan banyaknnya alat-alat medis yang menempel ditubuh pasien seperti: drain,infuse, selang NGT, kateter urine. Keadaan ini akan mempengaruhi pasien untuk melakukan gerakan sehingga gerakan menjadi terbatas. Hasil observasi luka didapatkan bahwa 5 orang yang tidak melakukan mobilisasi menunjukkan pinggir luka laparatomi memerah hari ke-4 dan 2 orang diantaranya setengah luka menjadi lembab dan memerah pada hari ke 6. Dari 10 orang yang tidak melakukan mobilisasi ditemukan 5 orang yang mengeluh timbulnya batuk. Berdasarkan fenomena diatas, maka peneliti tertarik ingin melakukan penelitian tentang pengaruh mobilisasi dini pasca pembedahan terhadap penyembuhan luka dan fungsi pernafasan pasien dengan post operasi abdomen di IRNA B Bedah RSUP Dr. M.Djamil Padang.

\section{METODE}

Penelitian ini merupakan penelitian Quasi eksperimental dengan pendekatan posttest control group design untuk mengetahui pengaruh mobilisasi dini pasca pembedahan abdomen terhadap penyembuhan luka operasi abdomen dan fungsi pernafasan. Populasinya adalah seluruh pasien pasca operasi abdomen yang dirawat diruang IRNA Bedah RSUP DR. M. Djamil Padang. Pengambilan sampel dalam penelitian ini menggunakan teknik Pengambilan sampel dengan teknik Sampling Kuota untuk mencapai sampel sebanyak 10 orang untuk setiap kelompok (kontrol dan perlakuan) dengan ciri tertentu yang sesuai dengan kepentingan penelitian. Sampling kuota adalah teknik untuk menentukan sampel dan populasi yang mempunyai ciri-ciri tertentu sampai jumlah yang diinginkan (Sugiyono,2005)

Kriteria pasien adalah yang melakukan operasi abdomen di RSUP DR. M. Djamil Padang dan dirawat diruang IRNA Bedah RSUP DR. M. Djamil Padang, pasien dengan 6-10 jam pasca operasi abdomen serta telah mendapat penyuluhan mobilisasi dini, tidak mengalami gangguan nutrisi, gangguan pernapasan dan penyakit penyerta (HIV, DM, sepsis, kanker ganas), tidak mengalami trauma,gawat abdomen, 
fraktur pelvis, kompresi fraktur, gangguan pernafasan. Penelitian ini melihat perbedaan penyembuhan luka dan fungsi pernafasan pada pasien post operasi abdemen yang menjalankan mobilisasi dini sesuai standar prosedur yang telah dibuatkan (kelompok perlakuan) dengan kelompok yang melakukan mobilisasi dini tidak sesuai standar. Hasil ini akan dianalisa menggunakan uji Mann Whitney dengan nilai signifikansi $\mathrm{p}=0.05$. Bila $\mathrm{p}<0.05$ ada perbedaan antara penyembuhan luka dan fungsi pernafasan pasien post operasi abdomen antara kelompok kontrol dengan perlakuan.

\section{HASIL DAN PEMBAHASAN}

Penelitian ini dilakukan di ruang bedah IRNA B RSUP Dr.M.Djamil Padang pada bulan Juni-September 2010 dengan subyek penelitian adalah pasien pasca abdomen yang mengalami bedah mayor(laparatomi) dan bedah minor masing-masing sebanyak 10 orang diberikan pendidikan tentang mobilisasi dini dan dipantau serta dibantu terus dalam melakukan mobilisasi dini (kelompok perlakuan), kemudian kelompok control untuk bedah mayor dan minor masingmasing 10 orang yang tanpa diberikan pendidikan tentang mobilisasi dini. Pemberian pendidikan kesehatan sudah dilakukan mulai pada saat preoperasi dan berlanjut sampai post operasi sehingga kelompok perlakuan benar dikendalikan dalam perlakuan, dari 40 responden lebih dari separoh responden laki-laki 25 orang $(62,5 \%)$,lebih dari separoh responden dengan umur $<50$ tahun sebanyak 27 orang $(67,5 \%)$, lebih dari separoh responden berstatus nutrisi normal sebanyak 24 orang $(60 \%)$.

Jumlah pasien laki-laki dan perempuan pada kelompok kontrol yang mengalami bedah mayor dan minor masingmasing sebanyak 5 orang, sedangkan pada kelompok perlakuan yang mengalami bedah mayor pasien laki-laki maisng-maisng 7 orang dan perempuan masing- masing 3 orang dapat dilihat pada tabel 1. Indikasi penyakit yang dilakukan bedah abdomen (laparatomi) dapat dilihat pada tabel 2.

Tabel 1 Distribusi Jenis Diagnosa Medis Pasien Paska Pembedahan Abdomen mayor pada kelompok kontrol dan perlakuan

\begin{tabular}{lcc}
\hline Diagnose Medis & Kelompok Kontrol & $\begin{array}{c}\text { Kelompok } \\
\text { Intervensi }\end{array}$ \\
\hline Adhesi post laparatomi & 1 & - \\
Laparatomi eksplorasi,perforasi gaster & 3 & - \\
Laparatomi eksplorasi,perforasi apendik & 4 & 2 \\
Laparatomi eksplorasi, kolostomi ec.ca rectum & 2 & 4 \\
laparatomi eksplorasi,pielolitotomy & - & 1 \\
herniostomi,hernioraphy & - & 1 \\
laparatomi eksplorasi,colostomi ec ileus obstruksi & - & 1 \\
laparatomi eksplorasi, hernia scrotalis dekstra & - & 1 \\
\hline Jumlah & 10 & 10 \\
\hline
\end{tabular}


Tabel 2 Distribusi Jenis Diagnosa Minor Pasien Paska Pembedahan Abdomen pada kelompok kontrol dan perlakuan

\begin{tabular}{lcc}
\hline Diagnosa Medis & Kelompok kontrol & Kelompok intervensi \\
\hline Apendiktomi & 9 & 4 \\
Hernioraphy & 1 & 5 \\
Funikocolectomi & - & 1 \\
\hline Jumlah & 10 & 10 \\
\hline
\end{tabular}

Pada tabel 3 digambarkan terdapat peningkatan rata-rata penyembuhan luka post operasi abdomen pada kelompok perlakuan bedah mayor dibanding dengan kelompok kontrol bedah mayor sebesar 5 maupun perlakuan bedah minor dibandingkan dengan kontrol bedah minor sebesar 5,1.

Setelah dianalisa dengan menggunakan uji mann whitney didapatkan nilai $\mathrm{p}<0,05$ yaitu $p=0.000$ yang berarti terdapat peningkatan penyembuhan luka post operasi abdomen pada kelompok perlakuan dibandingkan dengan kelompok control pada bedah mayor maupun bedah minor.

Hal ini menunjukkan bahwa pendidikan dan pemantauan pemberian mobilisasi dini sesegera mungkin memberikan penyembuhan luka operasi abdomen yang baik. Hal ini sesuai dengan yang disampaikan oleh Kozier,(1995) bahwa mobilisasi yang dilakukan akan memperlancar peredaran darah sekitar luka operasi sehingga sirkulasi nutrisi kearah luka terserap dengan baik dan proses penyembuhan luka cepat. Hal ini juga didukung oleh Rodt (2008) menggantiganti posisi di tempat tidur, berjalan dan melakukan gerakan-gerakan yang dianjurkan dokter atau perawat akan memperbaiki sirkulasi sehingga terhindar dari resiko pembekuan darah karena pembekuan darah ini dapat memperlambat penyembuhan luka. Seiring dengan pernyataan Rustam (1995) bahwa mobilisasi dapat mencegah terjadinya trombosis dan tromboemboli, dengan mobilisasi sirkulasi darah normal/lancar sehingga resiko terjadinya trombosis dan tromboemboli dapat dihindarkan. Mobilisasi segera setahap demi setahap berguna untuk membantu penyembuhan luka opersi. Hasil penelitian senada dengan Syahlinda (2008), bahwa pasien yang menjalani operasi laparatomi di IRNA B (bedah) RSUP M. Jamil Padang pada bulan Juli-Oktober 2007 mengalami penyembuhan luka insisi pasca operasi laparatomi dengan tidak terjadi komplikasi dengan melakukan mobilisasi.

Berdasarkan hasil pengamatan peneliti bahwa penyembuhan luka pada kelompok yang diberi penyuluhan dan pemantauan mobilisasi waktu perkembangan penyembuhan luka pada kelompok bedah mayor (laparatomi) sama dimana pelepasan drain sudah dapat dilakukan pada hari ke 3 dan pengangkatan jahitan selang seling sudah bisa dilakukan pada hari ke 7 dan hari ke 14 jahitan sudah dapat dilepas semua walaupun dari indeks masa tubuh klien ada 2 orang yang kurus sedangkan pada kelompok minor rata-rata pasien sudah dapat pulang pada hari ke 4 sedangkan di kelompok kontrolnya pasien pulang pada hari ke 7 . 
Table 3. Analisis Penyembuhan Luka Responden Post Operasi Abdomen kelompok Kontrol dengan Perlakuan pada Pembedahan Mayor dan Minor

\begin{tabular}{lcccc}
\hline Kelompok & Mean & $\begin{array}{c}\text { Peningkatan } \\
\text { rata-rata }\end{array}$ & SD \\
\hline Bedah Mayor & 5 & 5 & 0.000 & 0.000 \\
Kontrol & 10 & & 0.000 & \\
Perlakuan & 4.9 & 5,1 & 0.316 & 0.000 \\
Bedah Minor & 10 & & 0.000 & \\
Kontrol & & & \\
Perlakuan & &
\end{tabular}

Pada tabel 4 digambarkan terdapat peningkatan rata-rata fungsi pernafasan pada responden post operasi abdomen pada kelompok perlakuan bedah mayor dibanding dengan kelompok kontrol bedah mayor sebesar 2,1 maupun pada kelompok perlakuan bedah minor dibandingkan dengan kontrol bedah minor sebesar 0,6 .. Setelah dianalisa dengan menggunakan uji mann whitney didapatkan peningkatan fungsi pernafasan pada kelompok perlakuan dibandingkan dengan kelompok control pada bedah mayor dengan nilai $\mathrm{p}<0,05$ yaitu $\mathrm{p}=0.000$. namun tidak terjadi peningkatan fungsi pernafasan pada kelompok perlakuan bedah minor dibandingkan dengan kelompok kontrol bedah minor dengan nilai $p>0,05$ yaitu $p=0.067$.

Hal ini sesuai menurut Flanagan dan Mark-Maran,1997 yang menyatakan meningkatkan aktivitas fisik atau dilakukannya mobilisasi dini pasca bedah akan meningkatkan sirkulasi, nutrisi serta pengobatan yang adekuat pada luka pos operasi. Seiring dengan Garrison (2004) menyatakan salah satu manfaat dari mobilisasi dini adalah meningkatkan fungsi paru. Pasien dengan operasi mayor selalu menggunakan obat analgesik (antinyeri),penggunaan obat-obat nyeri pasca operasi dapat menekan pusat pernafasan sehingga frekuensi pernapasan dan pengembangan paru menurun, pengeluaran lendir dari paru-paru juga akan terganggu, dimana silia bronkkus yang bekerja normal mendorong

sekret dengan demikian reflek batukpun menurun dan kebersihan paru akan terganggu akibat terkumpunya sekret sehingga mdah terjadi infeksi. Efek anestesi umum adalah istirahat seluruh sistem dalam tubuh termasuk sistem pernafasan hal ini dapat menyebabkan Sekret yang menetap di bronkus dan paru akan menyebabkan pertumbuhan bakteri yang selanjutnya berkembang menjadi pneumonia. Infeksi pulmonal tetap berkembang mesti dilakukan intervensi untuk pencegahannya. Sekret yang stagnasi dapat dikurangi dengan mengubah posisi setiap dua jam sekali dan fisioterapi dada dengan menggunakan teknik posisi untuk mengalirkan sekret dari segmen paru (Potter \& Perry, 2006). Perawat harus mengajarkan kepada klien untuk nafas dalam dan batuk pada saat puncak efek analgesik yang terjadi 20-30 menit setelah pemberian obat (Potter \& Perry, 2006). Mobilisasi merupakan faktor yang menonjol dalam mempercepat penyembuhan atau pemulihan luka pasca bedah serta optimalnya fungsi pernafasan. Banyak keuntungan yang dapat diraih dari latihan naik turun tempat tidur dan berjalan pada periode dini pasca bedah, diantaranya peningkatan kecepatan kedalaman pernapasan, peningkatan sirkulasi, peningkatan berkemih dan metabolisme (Taylor, 1997). 
Pada kelompok bedah minor tidak terdapat perbedaan bermakna fungsi pernafasan pada kelompok perlakuan minor.hal ini bisa dikarenakan anestesi yang digunakan hanya spinal dan tidak mengenai system pernafasan,klien masih bisa bernafas normal. Berdasarkan hasil pengamatan peneliti bahwa selama proses penyembuhan klien dengan operasi minor baik control dan perlakuan pernafasan normal.yang menghambat klien bergerak adalah karena nyeri yang ditimbulkan akibat operasi sehingga hanya ada 3 orang yang menurunnya reflek batuk pada hari 1 post operasi.

Table 4. Analisis Fungsi Pernafasan Responden Post Operasi Abdomen kelompok Kontrol dengan Perlakuan pada Pembedahan Mayor dan Minor

\begin{tabular}{lcccc}
\hline Kelompok & Mean & $\begin{array}{c}\text { Peningkatan } \\
\text { Rata-rata }\end{array}$ & SD & $\mathrm{p}$ \\
\hline Bedah Mayor & 5,9 & 2,1 & 0.875 & 0.000 \\
Kontrol & 8 & & 0.000 & \\
Perlakuan & 7,4 & 0,6 & 0.966 & 0.067 \\
Bedah Minor & 8 & & 0.000 & \\
Kontrol & & & & \\
Perlakuan & & & & \\
\hline
\end{tabular}

\section{KESIMPULAN DAN SARAN}

Pemberian mobilisasi dini sesuai prosedur sangat membantu percepatan penyembuhan luka operasi yang mengalami post operasi abdomen baik untuk bedah mayor maupun minor sehingga penyembuhan bisa sesuai dengan konsep teori serta lama rawatan menjadi memendek.

Selanjutnya Pemberian mobilisasi dini sesuai prosedur sangat membantu meningkatkan fungsi pernafasan khususnya untuk pasien mengalami tirah baring lama pada pasien pasca operasi mayor abdomen sehingga dapat mencegah timbulnya komplikasi gangguan pernafasan

Peneliti menyarankan kepada RS agar menyediakan sarana dan prasana untuk kelancaran penyuluhan mobilisasi dini pasca pembedahan.

Perawat harus lebih memotivasi kliennya untuk melakukan mobilisasi dini post operasi abdomen dan bila perlu diperlukan pendampingan

\section{DAFTAR PUSTAKA}

Brunner \& Suddarth, 2002. Bedah Buku Ajar Medikal Vol 2 Ed 8. Jakarta: EGC.

Barbara C. Long, 1996. Praktek Keperawatan Medikal Bedah. Jakarta: EGC.

Ebell Mark, (2005). Early Mobilization Better for Acute Limb Injuries. Diakses pada tanggal 18 Januari $2010 \quad$ dari http://proquest.umi.com/pqdweb?did $=797615551 \&$ sid $=1 \& \mathrm{Fmt}=3 \&$ clientl $\mathrm{d}=45625 \& \mathrm{RTQ}=309 \& \mathrm{VName}=\mathrm{PQD}$

Effendy N., (1998). Dasar - Dasar Keperawatan kesehatan Masyarakat. Jakarta: EGC.

Ester Monica, (2001). Keperawatan Medikal Bedah : Pendekatan Sistem Gastro intestinal. Jakarta : EGC

Garrison, (2004). Dasar-dasar Terapi dan Latihan Fisik. Jakarata : Hypocrates

Kozier B., (1995). Fundamental of Nursing;Concepts,Process, and Practice Redwood City. California 
Niven Neil, (2002). Psikologi Kesehatan. Alih bahasa : Waluyo, Agung. Jakarta : EGC.

Notoatmojo S., (2003). Pendidikan dan Perilaku Kesehatan. Jakarta : Rineka Cipta

Notoatmojo S., (1997). Ilmu Kesehatan Masyarakat. Jakarta : Rineka Cipta.

Okwerita, (2008). Pengaruh Penyuluhan Terhadap Mobilisasi Dini Pasca Bedah Sesar Di Ruangan Kebidanan RSUD Sungai Dareh. Padang : Program Studi Ilmu Keperawatan Fakultas Kedokteran UNAND.

Potter \& Perry, (2006). Fundamental Keperawatan (Edisi 4). Jakarta : EGC
Priharjo, 1997. Pemenuhan Kebutuhan Aktivitas. Jakarta : EGC

Rustam, (1992). Sinopsis obstetri. Jakarta : EGC

Syahlinda, (2008). Efektifitas pedoman mobilisasi terhadap penyembuhan luka pada pasien paska laparatomi di irna b (bedah) RS. Dr. M. Jamil 